\title{
PERAN KONSEP DIRI DAN DUKUNGAN SOSIAL PADA KECEMASAN BERBICARA DI MUKA UMUM
}

\author{
Imam Sunardi \\ Fakultas Psikologi UIN Sunan Gunung Djati Bandung, Jl. A.H Nasution No. 105 Bandung \\ email: imamsunardi@yahoo.co.id
}

\begin{abstract}
Abstrak
Penelitian ini bertujuan untuk menelaah peran konsep diri dan dukungan sosial pada kecemasan berbicara di muka umum mahasiswa Fakultas Dakwah. Subjek penelitian terdiri atas 51 orang mahasiswa Fakultas Dakwah IAIN Sunan Gunung Djati Bandung semester VII, berasal dari Jurusan Bimbingan dan Penyuluhan Islam (BPI) dan Jurusan Pengembangan Masyarakat Islam (PMI). Data dikumpulkan melalui tiga skala yaitu skala kecemasan berbicara di muka umum, skala konsep diri, dan skala dukungan sosial. Hasil analisis regresi menunjukkan bahwa konsep diri berperan pada kecemasan berbicara di muka umum $\left(\mathrm{r}_{\text {Partial }}=-0,435 ; \mathrm{t}=-3,343 ; \mathrm{p}=0,002\right)$ dengan bobot sumbangan efektif sebesar 19,803 persen. Dukungan sosial memiliki peran yang tidak signifikan pada kecemasan berbicara di muka umum $\left(\mathrm{r}_{\text {Partial }}=0,117 ; \mathrm{t}=0,814 ; \mathrm{p}=0,575\right)$ dengan sumbangan efektif hanya 2,013 persen. Konsep diri memiliki aspek-aspek diri fisik, diri moral-etik, diri personal, diri keluarga, dan diri sosial. Diantara kelima aspek tersebut, hanya aspek diri personal yang berperan secara signifikan pada kecemasan berbicara di muka umum $\left(\mathrm{r}_{\text {Partial }}=-0,369 ; \mathrm{t}=-2,667 ; \mathrm{p}=0,010\right)$. Hasil lain menunjukkan bahwa tidak satupun aspek-aspek dukungan sosial secara signifikan berperan pada kecemasan berbicara di muka umum.
\end{abstract}

Kata kunci : kecemasan berbicara di muka umum, konsep diri, dukungan sosial.

\section{Abstract}

The objective of this research was to study the role of self concept and social support on public speaking anxiety of dakwah faculty students. Fifty one students of dakwah faculty of Sunan Gunung Djati Islamic Religion National Institute Bandung participated in this study. All of subjects studied at grade VII at the Islamic Counseling Program and Islamic Community Development Program. They were given three kinds of scales: public speaking anxiety scale, self concept scale, and social support scale. The results of regression analysis showed that self concept played a role on public speaking anxiety $\left(r_{\text {Partial }}=-0,435 ; t=-3,343 ; p=0,002\right)$ and the contribution was about 19,803 percent. Social support had no significant role on public speaking anxiety $\left(r_{\text {Partial }}=0,117 ; t=\right.$ 0,814; $p=0,575)$, and the contribution was about 2,013 percent only. Self concept had several aspects that were physical self, moral-ethic self, personal self, family self, and social self. One of those aspect, that was personal self, play a role on public speaking anxiety significantly $\left(r_{\text {Partial }}=-0,369 ; t=-2,667 ; p=0,010\right)$. Another result showed that no aspect of social support has role on public speaking anxiety significantly.

Key words : public speaking anxiety, self concept, social support. 


\section{PENDAHULUAN}

Mahasiswa Fakultas Dakwah sebagai calon sarjana bidang komunikasi Islam sangat dibutuhkan sumbangan pemikirannya untuk pembangunan masyarakat. Sumbangan-sumbangan dalam pembangunan dapat dilakukan melalui kemampuan mengkomunikasikan pikirannya, yakni berdakwah baik dengan tulisan maupun lisan dihadapan orang banyak guna mempengaruhi perilaku dan pikiran masyarakat ke arah yang positif.

Mahasiswa Fakultas Dakwah yang sedang praktek dakwah, seringkali mengalami kecemasan berbicara di muka umum. Kecemasan ini gejalanya dapat diamati, seperti berusaha untuk menghindar situasi yang mengharuskan untuk berbicara atau andaikan dipaksa untuk melakukannya maka individu tersebut tidak dapat menyampaikan ide-idenya dengan baik karena kurang konsentrasi, membisu, gagap, keluar keringat dingin yang berlebihan, gemetaran, dan tidak berani menatap muka pendengar. Gejala ini bisa jadi karena menjadi pusat perhatian banyak orang, baik mengenai penampilan maupun pembicaraannya, merasa dievaluasi, merasa statusnya lebih rendah dari pendengar, dan kurang kesiapan maupun pengalaman. Namun hal itu sebagai sesuatu yang wajar, karena beberapa mahasiswa lain pun mengalami hal yang sama.

Berbicara di muka umum menempati rangking teratas diantara ketakutan yang lain (Whalen, 1996). Penelitian Hurt (1978) di beberapa perguruan tinggi di Amerika Serikat hasilnya menunjukkan bahwa 10 persen sampai 20 persen mahasiswa menderita kecemasan dalam berkomunikasi. Lebih lanjut ia menyatakan bahwa kecemasan dalam berkomunikasi banyak mengganggu aspek kehidupan manusia, baik fungsinya sebagai sumber komunikasi maupun sebagai penerima pesan, karena kecemasan mengakibatkan komunikasi tidak efektif.

Penelitian yang dilakukan Trefina (1990) terhadap mahasiswa IKIP Yogyakarta menunjukan bahwa ada hubungan yang negatif antara konsep diri dengan kecemasan komunikasi oral. Artinya semakin tinggi konsep diri yang dimiliki maka semakin rendah tingkat kecemasan komunikasi oralnya dan penelitian yang dilakukan oleh Alwi (2002) terhadap remaja di panti asuhan menunjukkan bahwa dukungan sosial yang diterima turut menurunkan kecemasan berbicara di muka umum. Kepercayaan diri merupakan salah satu faktor yang dapat mempengaruhi adanya kecemasan dalam berkomunikasi (Rakhmat, 1985). Seseorang tanpa dukungan sosial dapat merasa terganggu secara psikologis, demikian juga ketika mengalami kecemasan berbicara di muka umum. Pada orang yang memperoleh dukungan sosial yang memadai maka kecemasan yang dihadapinya akan dapat dikurangi. Orang yang memiliki dukungan sosial yang relatif tinggi sedikit mengalami gangguan psikologis dan psikis (Mermelmstein, Cohen \& Lich-tenstein, 1986).

Berdasarkan kondisi yang terjadi pada mahasiswa Fakultas Dakwah yang sedang melaksanakan praktek dakwah maka dapat dikemukakan bahwa permasalahannya adalah adanya indikasi kecemasan berbicara di muka umum dikarenakan rendahnya konsep diri dan dukungan sosial, oleh karena itu perlu ditelaah dalam penelitian ini peran konsep diri dan dukungan sosial pada mahasiswa Fakultas Dakwah yang sedang melaksanakan praktek dakwah yang mengalami kecemasan berbicara di muka umum.

Tujuan penelitian ini adalah untuk menelaah peran konsep diri dan dukungan sosial pada mahasiswa Fakultas Dakwah yang sedang praktek dakwah dalam usahanya untuk mengurangi kecemasan berbicara di muka umum.

Hasil penelitian dapat diketahui lebih jelas mengenai peran konsep diri dan dukungan sosial pada kecemasan berbicara di muka umum mahasiswa Fakultas Dakwah yang sedang praktek dakwah. Penelitian ini diharapkan berguna antara lain dalam pengembangan ilmu pengetahuan, yaitu dapat memberikan informasi mengenai kasus-kasus yang berhubungan dengan konsep diri, dukungan sosial, dan kecemasan berbicara di muka umum dalam bidang komunikasi atau psikologi sosial.

Selain itu, secara praktis hasil penelitian ini diharapkan dapat memberikan sumbangan bagi lembaga-lembaga pendidikan yang menyediakan program dakwah mengenai pentingnya meningkatkan konsep diri dan dukungan sosial dalam rangka menurunkan kecemasan berbicara di muka umum pada mahasiswanya. 


\section{Kecemasan berbicara di muka umum}

Braun \& Darwyn (dalam Davidson \& Neale, 1978) menyatakan bahwa kecemasan merupakan perasaan kekhawatiran, keprihatinan atau ketakutan. Lindgren \& Hyrne (1971) memberi pengertian tentang kecemasan sebagai keadaan emosional yang tidak menyenangkan, serupa dengan ketakutan, langsung terhadap sumber yang agak meragukan, sering di masa depan. Pendapat serupa disampaikan oleh Gilmer (1975) yang mendefinisikan kecemasan sebagai kondisi emosi yang tidak menyenangkan yang ditandai dengan perasaan takut, gelisah, dan khawatir terhadap apa yang akan terjadi di masa yang akan datang. Misalnya tentang karier di masa depan dan menghadapi ujian (Halgin \& Whitbourne 1994). Kecemasan dengan demikian merupakan keadaan emosi tidak menyenangkan terhadap obyek atau sumber yang tidak jelas di masa depan atau masa mendatang yang dianggap mengancam bagi diri seseorang. Keadaan emosi ini bersifat subyektif yang ditandai dengan perasaan takut, gelisah, dan khawatir. Individu yang mengalami kecemasan biasanya membuat penilaian yang berlebihan terhadap kejadian. Kecemasan ini apabila dibiarkan berlarut-larut dapat menyebabkan gangguan pada fungsi fisiologis.

Kecemasan berbicara di depan umum atau demam panggung, merupakan ketakutan berkaitan dengan komunikasi yang dilakukan di depan umum atau orang banyak. Kecemasan ini bukan disebabkan oleh ketidakmampuan dalam pengetahuan, namun lebih bersifat redaksional. Philips (dalam McCroskey, 1977) mengistilahkan kecemasan berbicara dengan reticence, yaitu sebagai ketidakmampuan mengikuti diskusi secara aktif, ketidakmampuan mengembangkan percakapan, ketidakmampuan menjawab pertanyaan yang diajukan di kelas atau dalam pekerjaan yang bukan disebabkan oleh kurangnya pengetahuan, tetapi dikarenakan ketidakmampuan dalam menyusun kata-kata, ketidakmampuan menyampaikan pesan secara sempurna sekalipun sebelumnya telah disiapkan secara sempurna.

Burgoon dan Ruffner (1978) menggunakan istilah unwillingness untuk menggambarkan kecemasan tidak secara spesifik, yakni dalam kaitannya dengan komunikasi saja, namun juga berkaitan dengan kecemasan pada waktu melakukan sesuatu dalam situasi umum, misalnya menari, menyanyi dan bermain musik. Mereka mengistilahkan kecemasan berbicara di muka umum sebagai unwillingness communication, yaitu suatu kondisi individu yang merasa cemas dalam menghadapi situasi komunikasi, khususnya situasi komunikasi di muka umum (public setting).

Devito (1995) membuat istilah kecemasan berbicara di muka umum sebagai speaker apprehension, yaitu keadaan takut atau cemas dalam interaksi komunikasi dan menekankan bahwa fenomena kecemasan berbicara di muka umum berpusat pada pembicara. Lebih lanjut ia menyatakan bahwa speaker apprehension mengandung dua perspektif, yaitu perspektif kognitif dan perspektif perilaku.

Kecemasan berbicara di muka umum termasuk dalam kecemasan yang bersifat state anxiety, yaitu kecemasan yang bersifat sementara. Apabila peristiwa penyebab kecemasan itu berlalu, maka individu yang mengalami kecemasan itu akan kembali normal seperti sediakala. Individu yang mengalami kecemasan yang bersifat state anxiety ini bukanlah orang yang mengalami gangguan kepribadian, namun demikian harus dikurangi sehingga individu dapat menyampaikan ide-ide dan kemampuannya dengan baik kepada orang lain.

Burgoon dan Ruffner (1978) mengungkapkan aspek-aspek kecemasan dalam berkomunikasi atas unwillingness, unrewarding, dan control.

Unwillingness (keengganan), yaitu tidak ada minat untuk berpartisipasi dalam komunikasi. Individu berusaha menghindari untuk berbicara di muka umum.

Unrewarding (tanpa ganjaran), yaitu tidak adanya penghargaan dalam berkomunikasi atau adanya peningkatan hukuman dalam berkomunikasi sebelumnya. Kecemasan komunikasi disebabkan oleh adanya penolakan dari orang lain, adanya pemanfaatan terhadap orang lain dan komunikasi.

Uncontrol (tidak terkendali), yaitu kurangnya kontrol individu terhadap situasi dan lingkungan komunikasi (termasuk tempat dan peralatan) yang dapat menyebabkan kecemasan. Faktor lingkungan dapat menyebabkan kecemasan, yaitu berhubungan dengan lokasi tempat berlangsungnya pembicaraan, kurang kontrol terhadap lingkungan sehingga pada saat pembicaraan berlangsung dapat menyebabkan kecemasan pada pembicara. 


\section{Konsep diri}

Konsep diri adalah suatu yang ada pada diri seseorang, berupa pandangan yang berasal dari dalam diri orang yang bersangkutan. Secord \& Backman (1974) mengatakan bahwa konsep diri adalah proses pemikiran dan perasaan terhadap diri sendiri yang meliputi tubuh, penampilan dan perilaku. Rosenberg (dalam Partosuwido, 1992) menyatakan bahwa konsep diri merupakan struktur mental, suatu totalitas pikiran, perasaan dalam hubungannya dengan diri sendiri. Burns (1982), mengemukakan bahwa konsep diri merupakan kesan individu terhadap dirinya secara kese-uruhan meliputi pendapatan tentang diri sendiri, tentang citra diri di mata orang lain, dan hal-hal yang dapat dicapai. Selain itu, Shevelson dan Bolus (1982) menyatakan bahwa konsep diri merupakan konsep dasar individu mengenai diri, pikiran dan pendapat tentang diri sendiri, perbandingan dirinya dengan orang lain, dan perbandingan dengan hal-hal ideal yang ditentukannya sendiri untuk dicapai lebih lanjut.

Fitts (dalam Tjipsastram, 1996) membagi konsep diri atas dua dimensi, yakni diri internal dan diri eksternal, Diri internal terdiri atas aspek diri identitas, diri perilaku, dan diri penilai. Dimensi eksternal meliputi atas: diri fisik, diri moral-etik, diri personal, diri keluarga, dan diri sosial. Diri fisik (physical self) menggambarkan bagaimana individu memandang tubuh, keadaan kesehatan, penampilan fisik, dan seksualitasnya. Diri moral-etik (moral-ethical self) ditinjau berdasarkan kerangka acuan moral-etik, nilai-nilai moral, hubungannya dengan Tuhan, dan penilaiannya sebagai orang baik atau buruk, dan rasa puas terhadap kehidupan keagamaan. Diri personal (personal Self) merefleksikan perasaan seseorang terhadap nilai-nilai dirinya sebagai pribadi, seberapa besar individu menilai kemampuan dirinya dan menggambarkan identitas dirinya. Penilaian terhadap kepribadiannya ini terlepas dari penilaian terhadap tubuh dan hubungannya dengan orang lain. Diri keluarga ( $f a-$ mily self) merupakan persepsi diri individu dalam kaitannya dengan keluarga dan teman dekat. Sejauhmana perasaan dan penilaian seseorang sebagai anggota keluarga, serta berharga dan bernilai sebagai anggota keluarga dan teman dekat. Diri sosial (sosial self) merupakan persepsi diri individu dalam kaitannya dengan interaksi sosialnya dengan orang lain secara umum. Sejauhmana ia merasa adekuat dalam interaksinya dengan orang lain dan lingkungannya yang luas.

\section{Dukungan sosial}

Leavy (dalam Ganster, Fusilier, dan Mayer, 1986) menyatakan bahwa dukungan sosial merupakan hubungan yang di dalamnya terkandung pemberian bantuan dan hubungan itu memiliki nilai khusus. Johnson dan Johnson (1991) menyebutkan bahwa dukungan sosial adalah pemanfaatan sumber-sumber di lingkungan individu untuk membuat kehidupan menjadi lebih baik dengan cara meningkatkan kemampuan pada diri seseorang dengan memberikan bantuan berupa dorongan, penerimaan dan perhatian.

Srason (1998) mendefinisikan dukungan sosial sebagai adanya pemberian informasi baik secara verbal maupun non verbal, pemberian bantuan tingkah laku atau materi melalui hubungan sosial yang akrab atau hanya disimpulkan dari keberadaan mereka yang membuat seseorang merasa diperhatikan, bernilai dan dicintai. Sedangkan House (dalam Cohen dan Syme, 1985) mendefinisikan dukungan sosial sebagai suatu bentuk hubungan sosial yang bersifat menolong dengan melibatkan aspek-aspek emosi, informasi, bantuan instrumen, dan penilaian.

House (dalam Cohen dan Syme, 1985) membagi dukungan sosial atas empat aspek, yakni dukungan emosional, dukungan penilaian, dukungan informatif, dan dukungan instrumen. Dukungan emosional merupakan pemberian dukungan berupa ungkapan empati, kepedulian dan perhatian terhadap orang yang bersangkutan. Dukungan penilaian/penghargaan berupa ungkapan hormat secara positif kepada seseorang, dorongan maju atau persetujuan dengan gagasan atau perasaan individu dan perbandingan positif orang itu dengan orang-orang lain. Dukungan informatif merupakan bentuk dukungan berupa pemberian nasehat, saran, petunjuk-petunjuk, dan umpan balik. Dukungan instrumental merupakan bentuk dukungan yang bersifat langsung, misalnya bantuan peralatan, pekerjaan dan keuangan.

Menurut Cohen dan Syme (1985) terdapat enam faktor yang dianggap mempengaruhi keefektifan pemberian dukungan sosial, yaitu pemberi dukungan, jenis dukungan, 
penerima dukungan, permasalahan, waktu pemberian dukungan dan lamanya pemberian dukungan. Bantuan yang diterima oleh seseorang akan melindungi atau mengurangi dari keadaan yang tidak menyenangkan, seperti yang dinyatakan Safarino (1998) bahwa dukungan sosial akan melindungi seseorang dari keadaan yang menegangkan atau membuat cemas. Apabila dukungan sosial yang diterima cukup, maka kesehatan fisik dan mental akan baik. Dukungan sosial yang diberikan oleh dosen, orang tua, dan teman-teman akan berfungsi sebagai penguat sehingga dapat mengurangi kecemasan ketika berbicara di muka umum.

Hubungan antara variabel kecemasan berbicara di muka umum, konsep diri dan dukungan sosial inilah yang akan ditelaah lebih jauh, yakni peran konsep diri dan dukungan sosial pada kecemasan berbicara di muka umum mahasiswa Fakultas Dakwah yang sedang praktek dakwah.

\section{Hipotesis}

Hipotesis penelitian adalah terdapat peran antara konsep diri dan dukungan sosial pada kecemasan berbicara di muka umum pada mahasiswa Fakultas Dakwah. Semakin tinggi konsep diri dan dukungan sosial, maka semakin rendah kecemasan berbicara di muka umum.

\section{METODE PENELITIAN}

Penelitian terdiri atas variabel bebas, yaitu konsep diri dan dukungan sosial, serta variabel terikat, yaitu kecemasan berbicara di muka umum. Kecemasan berbicara di muka umum yang akan diukur adalah kecamasan berdakwah di muka umum dengan menggunakan alat ukur yang diadaptasi dari Alwi (2002) berdasarkan aspek yang diungkap, yaitu keengganan (menghindari kegiatan berbicara di muka umum), tanpa ganjaran (tidak adanya penghargaan dalam berbicara), dan tidak terkendali (kurangnya kontrol terhadap situasi tempat berbicara). Konsep diri disusun berdasarkan kerangka teori dari Fitts yang telah di adaptasi dari Sutarlinah Sukadji (dalam Tjipsastra, 1996). Kerangka teori ini mengungkapkan dua dimensi konsep diri, yaitu dimensi internal dan eksternal yang dipadukan. Dimensi internal meliputi diri identitas, diri pelaku, dan diri penilai. Sedangkan dimensi eksternal meliputi diri fisik, diri etik-moral, diri pribadi atau personal, diri keluarga, dan diri sosial. Dukungan sosial diukur dengan alat ukur yang dibuat sendiri oleh penulis berdasarkan konsep yang dikemukakan oleh House (dalam Cohen dan Syme, 1985) dengan aspek-aspek dukungan sosial yang diungkap adalah dukungan emosional, dukungan penilaian atau penghargaan, dukungan informatik, dan dukungan instrumental. Skor yang diperoleh subyek menunjukan tingkat dukungan sosial.

Subjek penelitian adalah mahasiswa Fakultas Dakwah pada Institut Agama Islam Negeri (IAIN) Sunan Gunung Djati Bandung yang sedang mengikuti praktek dakwah langsung berhadapan dengan masyarakat. Teknik pengambilan subyek dilakukan dengan purposive sampling. Dalam pelaksanaan pengumpulan data, skala disebarkan kepada 92 orang, akan tetapi yang dikembalikan kepada penulis sebanyak 51 buah.

Setiap skala dikembangkan dalam butirbutir pernyataan, berdasarkan empat kategori jawaban, yaitu sangat sesuai (SS), sesuai (S), tidak sesuai (TS), dan sangat tidak sesuai (STS). Skor tiap butir berkisar dari 1 sampai 4 .

Skala kecemasan berbicara di muka umum berjumlah 42 butir, lima butir diantaranya gugur sehingga yang digunakan dalam pengujian hipotesis sebanyak 37 butir. Butirbutir valid skala kecemasan berbicara di muka umum memiliki korelasi $r_{x y}$ antara 0,328 hingga 0,691 dan korelasi butir-total $\mathrm{r}_{\mathrm{bt}}$ dari 0,283 sampai 0,666 dengan peluang galat $p$ dari 0,000 hingga 0,021 .

Skala konsep diri berjumlah 100 butir, sebanyak 23 butir diantaranya gugur sehingga yang digunakan dalam pengujian hipotesis sebanyak 77 butir. Butir-butir valid skala konsep diri memiliki korelasi $r_{x y}$ antara 0,272 hingga 0,669 dan korelasi butir-total $\mathrm{r}_{\mathrm{bt}}$ dari 0,253 sampai 0,651 dengan peluang galat $p$ dari 0,000 hingga 0,035 .

Skala dukungan sosial berjumlah 40 butir, sebanyak tujuh butir diantaranya gugur sehingga yang digunakan dalam pengujian hipotesis sebanyak 33 butir. Butir-butir valid skala dukungan sosial memiliki korelasi $r_{x y}$ antara 0,291 hingga 0,762 dan korelasi butir-total $r_{b t}$ dari 0,257 sampai 0,735 dengan peluang galat $p$ dari 0,000 hingga 0,033 . 
Uji-keandalan dalam penelitian ini menggunakan teknik Hoyt. Hasil uji keandalan atau reliabilitas skala kecemasan berbicara di muka umum diperoleh $r_{t t}=0,919 p=0,000$ (andal), skala konsep diri diperoleh $r_{t t}=0,957$ $p=0,000$ (andal), dan skala dukungan sosial diperoleh $\mathrm{r}_{\mathrm{tt}}=0,922 p=0,000$ (andal).

Teknik analisis data yang digunakan dalam penelitian ini adalah analisis regresi ganda (multiple regression) yang digunakan untuk mencari prediksi konsep diri dan dukungan sosial pada kecemasan berbicara di muka umum.

\section{HASIL PENELITIAN DAN PEMBAHASAN}

\section{Uji persyaratan analisis}

Uji asumsi normalitas sebaran kecemasan berbicara di muka umum menggunakan statistik Kai-Kuadrat $\left(\chi^{2}\right)$ dengan bantuan program SPS-2000 menunjukan harga Kai Kuadrat sebesar 5,519 (db=9) dan peluang galat $p$ sebesar 0,787 (normal). Uji linieritas hubungan menunjukan bahwa variabel konsep diri berkolerasi dengan kecemasan berbicara di muka umum dengan "beda" antara derajat ke-1 dengan derajat ke-2 yang tidak signifikan $(p=$ 0,790 ) sehingga dapat dikatakan bahwa hubungan antara kedua variabel tersebut linier. Dukungan sosial dengan kecemasan berbicara di muka umum dengan "beda" antara derajat ke-1 dengan derajat ke-2 yang tidak signifikan $(p=0,796)$ sehingga dapat dikatakan bahwa hubungan antara kedua variabel tersebut linier. Uji kolinieritas hubungan sesama variabel bebas dalam hal ini konsep diri dan dukungan sosial, menunjukkan besarnya korelasi antara konsep diri dengan dukungan sosial sebesar 0,600 dengan peluang galat $p$ sebesar 0,000. Hasil ini menunjukkan bahwa tidak ada kolinieritas diantara sesama variabel bebas karena korelasi tersebut di bawah 0,800.

\section{Hasil uji hipotesis}

Hipotesis yang diuji dalam penelitian ini adalah terdapat peran konsep diri dan dukungan sosial pada kecemasan berbicara di muka umum pada mahasiswa Fakultas Dakwah. Hipotesis tersebut terdiri atas dua variabel bebas (prediktor) yakni konsep diri dan dukungan sosial, serta terdapat satu variabel terikat (kriterium) yakni kecemasan berbicara di muka umum.
Hasil analisis regresi menunjukan bahwa dalam model penuh (melibatkan seluruh prediktor) konsep diri memiliki harga koefisien regresi $-0,270$ dengan $r_{\text {Parsial }}$ sebesar $-0,435, t$ sebesar $-3,343$ dan peluang galat $p=0,002$ (sangat signifikan), sedangankan dukungan sosial memiliki koefisien regresi sebesar 0,160 dengan harga $r_{\text {Parsial }}$ sebesar $0,117 t$ sebesar 0,814 dan peluang galat $p=0,575$ (nirsignifikan). Dalam model penuh tersebut sumbangan efektif konsep diri sebesar 19,803 persen sedangkan dukungan sosial hanya sebesar 2,013 persen. Hasil uji menunjukan bahwa konsep diri merupakan prediktor yang dapat diandalkan dalam memprediksi kecemasan berbicara di muka umum.

Hipotesis yang diuji menghendaki seluruh variabel bebas atau prediktor, yakni konsep diri dan dukungan sosial masuk ke dalam persamaan regresi, sedangkan pada tabel tersebut terlihat bahwa dalam model akhir variabel dukungan sosial dikeluarkan karena korelasinya signifikan, hanya konsep diri yang dipertahankan. Hasil ini menunjukan bahwa hipotesis nol $\left(\mathrm{H}_{0}\right)$ yang diterima. Lebih tegasnya dapat dikatakan bahwa hanya konsep diri yang berperan pada kecemasan berbicara di muka umum di kalangan mahasiswa Fakultas Dakwah.

Hasil analisis diperoleh korelasi $r$ sebesar 0,455 dengan koefisisen determinasi $r^{2}$ sebesar 0,207. Hal ini dapat diartikan bahwa konsep diri memiliki peran sebesar 20,7 persen pada kecemasan berbicara di muka umum. Peran aspek-aspek konsep diri terhadap kecemasan berbicara di muka umum

Konsep diri memiliki lima aspek yaitu diri fisik, diri etik-moral, diri pribadi, diri keluarga, dan diri sosial. Kelima aspek tersebut ternyata tidak seluruhnya menjadi prediktor yang patut diandalkan. Aspek yang signifikan hanya ditemukan pada aspek diri pribadi. Sumbangan efektif terbesar dan signifikan aspek-aspek konsep diri hanya diberikan oleh aspek diri pribadi yakni sebesar 20,806 persen, sedangkan aspek-aspek lainnya memiliki sumbangan yang sangat kecil dan tidak signifikan.

\section{Peran aspek-aspek dukungan sosial terhadap kecemasan berbicara di muka umum}

Dukungan sosial memiliki empat aspek yaitu dukungan emosional, penilaian, informatif dan instrumental. Hasil analisis menunjukkan bahwa tidak satupun dari keempat 
aspek tersebut dipertahankan sebagai prediktor, sehingga mengakibatkan kecilnya sumbangan relatif dan sumbangan efektif masing-masing aspek dukungan sosial terhadap kecemasan berbicara di muka umum, yaitu hanya sebesar 5,825 persen. Pada situasi seperti ini maka analisis regresi reduksi bertahap (removing stepwise) tidak bisa dilakukan, karena tidak satupun aspek dukungan sosial yang berkorelasi secara signifikan.

\section{Pembahasan}

Berbicara di muka umum merupakan kompetensi yang mutlak dimiliki oleh para mahasiswa Fakultas Dakwah. Kelak setelah mereka menjadi sarjana komunikasi Islam maka mereka akan banyak berhadapan dengan orang dan menggunakan keterampilan berbicara di muka umum sebagai alat atau metode utamanya. Hambatan dalam berbicara di muka umum berupa kecemasan akan menjadi persoalan besar dalam upayanya menyampaikan syiar Islam. Ketidakmampuan dalam berbicara di muka umum langsung maupun tidak langsung akan menurunkan kredibilitas dirinya sebagai juru dakwah.

Pengujian hipotesis penelitian dilakukan dengan melibatkan dua variabel bebas yaitu konsep diri dan dukungan sosial. Hasil uji menunjukkan bahwa hanya variabel konsep diri yang merupakan prediktor bagi kecemasan berbicara di muka umum, sedangkan dukungan sosial daya prediksinya tidak signifikan.

Deskriptif data menunjukkan bahwa sebanyak 23,5 persen subjek memiliki kecemasan berbicara di muka umum dengan kategori tinggi dan 7,8 persen dengan kategori sangat tinggi. Data ini mengisyaratkan adanya "masalah" pada 31,3 persen subjek dalam berbicara di muka umum. Lebih rinci lagi, sebanyak 15,7 persen subjek mengalami kecemasan yang berkaitan dengan keengganannya untuk berbicara di muka umum, 9,8 persen subjek mengalami hambatan dalam hal berbicara di muka umum yang dipandangnya tanpa ganjaran yang memadai, dan sebanyak 23,6 persen subjek mengalami persoalan dengan tidak terkendalinya situasi serta materi pembicaraan. Secara umum distribusi subjek dalam kategori atau tingkat kecemasan berbicara di muka umum dapat dikatakan cukup merata, yang menyebabkan tidak adanya perbedaan yang signifikan dalam hal kecemasan berbicara di muka umum antara rerata empirik dan rerata hipotetiknya.
Praktek dakwah pada jurusan BPI dan PMI dilakukan pada semester VII. Dalam pelaksanaannya setiap mahasiswa diwajibkan untuk menyiapkan materi dakwah dan menyampaikannya di depan orang banyak, serta turut pula disaksikan oleh rekan sesama mahasiswa dan dosen pembimbing. Sebenarnya hal tersebut sudah sering dilakukan pada enam semester sebelumnya, terutama ketika para mahasiswa menggunakan laboratorium dakwah di lingkungan Fakultas Dakwah. Kenyataannya masih ada 31,2 persen mahasiswa yang mengalami kecemasan, diartinya bahwa situasi praktik dipandang sangat berbeda dengan situasi laboratorium. Para mahasiswa menganggap bahwa praktik dakwah merupakan gambaran nyata proses dakwah yang sebenarnya. Anggapan semacam itu tentu saja menambah beban bagi dirinya sehingga kecemasan akan bertambah pula.

Hasil uji yang menunjukkan konsep diri sebagai prediktor bagi kecemasan berbicara di muka umum sejalan dengan beberapa hasil penelitian sebelumnya. Konsep diri merupakan faktor yang dianggap mampu mengurangi kecemasan berbicara di muka umum. Hasil penelitian Mitchell (dalam Burns,1979) menunjukkan bahwa individu yang memiliki konsep diri yang baik semakin berkurang wujud kecemasannya. Penelitian lain yang dilakukan oleh Trefina (1990) terhadap mahasiswa IKIP Yogyakarta, hasilnya menunjukkan bahwa ada hubungan yang negatif antara konsep diri dengan kecemasan komunikasi oral.

James (dalam Burns, 1979) berpendapat bahwa konsep diri merupakan organisasi sikap diri yang terbentuk melalui proses penerimaan diri, harga diri, atau penilaian diri. Penerimaan diri, harga diri, dan penilaian diri berkembang dari pengalaman interaksi manusia dengan keluarga, teman sebaya, dan masyarakat pada umumnya. Pernyataan senada dikemukakan oleh James (dalam Hurlock, 1979) bahwa konsep diri merupakan faktor yang sangat penting terhadap perkembangan kepribadian individu. Begitu pula halnya dengan keterampilan berbicara di muka umum yang tidak muncul begitu saja melainkan merupakan hasil dari pengalaman terus menerus dan proses pembelajaran.

Analisis lebih lanjut dilakukan terhadap peran aspek-aspek konsep diri pada kecemasan berbicara di muka umum. Hasilnya menunjukkan bahwa dari lima aspek konsep diri, 
hanya aspek diri pribadi atau personal yang memiliki peran signifikan, sedangkan aspekaspek lainnya tidak signifikan. Fitts (dalam Tjipsastra, 1996) menjelaskan bahwa diri personal mereflesikan perasaan seseorang terhadap nilai-nilai dirinya sebagai pribadi, seberapa besar individu menilai kemampuan dirinya dan menggambarkan identitas dirinya. Penilaian terhadap kepribadiannya ini terlepas dari penilaian terhadap tubuh dan hubungannya dengan orang lain.

Orang dengan konsep diri personal tinggi memiliki ciri-ciri selalu bersemangat dalam menghadapi hidup, mempunyai kemampuan untuk mengendalikan diri, tenang, tidak pendendam dan selalu mempertimbangkan dampak sebelum bertindak atau berperilaku. Orang seperti ini merasa dirinya cukup cerdas, ramah dan menerima puas dengan keadaan dirinya. Ciri lain orang dengan konsep diri personal tinggi adalah tidak mudah menyerah, mampu menerima tanggung jawab, tanpa ragu-ragu dalam membuat keputusan, dan dapat menyelesaikan masalah dengan berpikir jernih.

Berbeda dengan konsep diri, dalam penelitian ini ternyata dukungan sosial memiliki korelasi yang tidak signifikan dengan kecemasan berbicara di muka umum. Beberapa penelitian sebelumnya menunjukkan hasil yang sebaliknya. Diantaranya peneliti Alwi (2002) yang menemukan bahwa dukungan sosial yang diterima remaja di panti asuhan menurunkan kecemasan berbicara di muka umum. Bahkan Mermelmstein, Cohen dan Lichtenstein (1986) menyatakan bahwa orang yang memiliki dukungan sosial yang relatif tinggi sedikit mengalami gangguan psikologis. Seseorang tanpa dukungan sosial dapat merasa terganggu secara psikologis, demikian juga ketika mengalami kecemasan berbicara di muka umum. Pada orang yang memperoleh dukungan sosial yang memadai maka kecemasan yang dihadapinya akan dapat dikurangi.

Kemungkinan lain yang menjadi penyebab penolakan hipotesis adalah model teoritis yang digunakan sebagaimana tergambar dalam kerangka berpikir penelitian. Dalam kerangka tersebut digambarkan bahwa kecemasan berbicara di muka umum diprediksi oleh dua variabel bebas secara bersama-sama yaitu konsep diri dan dukungan sosial. Hasil uji korelasi lugas menunjukan korelasi antara konsep diri dengan kecemasan berbicara di muka umum sebesar $-0,455$ dengan peluang galat $p=0,001$ (sangat signifikan), sedangkan korelasi antara dukungan sosial dengan kecemasan berbicara di muka umum sebesar -0,190 dengan peluang galat $p=0,179$ (nirsignifikan). Temuan lain ya-ng cukup penting adalah korelasi lugas antara sesama variabel bebas (antara konsep diri dengan dukungan sosial) sebesar 0,600 dengan peluang galat $p=0,000$ (sangat signifikan).

Korelasi yang sangat signifikan antara konsep diri dan dukungan sosial sebesar 0,600 dapat dipandang cukup tinggi. Interprestasi dari temuan ini adalah adanya kemungkinan dukungan sosial dapat berperan terhadap kecemasan berbicara di muka umum akan tetapi secara tidak langsung. Model teoritis yang lebih tepat adalah dukungan sosial berperan pada pembentukan konsep diri, setelah itu konsep diri berperan pada kecemasan berbicara di muka umum. Walaupun demikian, pembuktian atas model tersebut memerlukan penelitian lebih lanjut terutama untuk menguji apakah benar dukungan sosial merupakan salah satu prediktor bagi konsep diri.

\section{SIMPULAN DAN SARAN}

\section{Simpulan}

Pertama. Konsep diri berperan dalam kecemasan berbicara di muka umum pada mahasiswa Fakultas Dakwah di IAIN Sunan Gunung Djati Bandung. Pola hubungan kedua variabel tersebut memiliki arah negatif sehingga konsep diri yang positif akan menurunkan kecemasan berbicara di muka umum, sebaliknya konsep diri yang negatif cenderung meningkatkan kecemasan berbicara di muka umum.

Kedua. Peran dukungan sosial pada kecemasan berbicara di muka umum tidak signifikan. Hal ini berarti bahwa dukungan sosial bukan menjadi prediktor bagi kecemasan berbicara di muka umum pada mahasiswa Fakultas Dakwah.

Ketiga. Konsep diri memiliki aspekaspek diri fisik, diri moral-etik, diri personal, diri keluarga, dan diri sosial. Diantara kelima aspek tersebut, hanya aspek diri personal yang berperan sangat signifikan pada kecemasan berbicara di muka umum. Semakin positif konsep diri personal ini cenderung akan menurunkan kecemasan berbicara di muka umum, sebaliknya konsep diri personal yang negatif 
cenderung meningkatkan kecemasan berbicara di muka umum. Keempat. Dukungan sosial memiliki aspek-aspek: dukungan emosional, dukungan penilaian, dukungan informatif, dan dukungan instrumental. Seluruh aspek dukungan sosial tersebut tidak signifikan berperan pada kecemasan berbicara di muka umum.

\section{Saran}

Pertama, bagi dosen pembimbing Fakultas Dakwah IAIN Sunan Gunung Djati Bandung. Diperlukan upaya pengamanan khusus bagi mahasiswa yang mengalami kecemasan berbicara di muka umum dalam kategori tinggi dan sangat tinggi. Penanganan khusus ini bisa dilakukan dengan bimbingan dan penyuluhan serta upaya peningkatan keterampilan berbicara di muka umum dan bimbingan materi dakwah.

Kedua. Upaya meminimalisir kecemasan berbicara di muka umum dapat dilakukan dengan meningkatkan konsep diri para mahasiswa. Para mahasiswa senanitasa didorong untuk selalu bersemangat dalam menghadapi hidup, mempunyai kemampuan untuk mengendalikan diri, tenang, tidak pendendam dan selalu mempertimbangkan dampak sebelum bertindak atau berperilaku. Yakinkan para mahasiswa tersebut bahwa mereka orang yang cukup cerdas, ramah dan menerima puas dengan keadaan dirinya. Para mahasiswa didorong pula untuk tidak mudah menyerah, mampu menerima tanggung jawab, tanpa ragu-ragu dalam membuat keputusan, dan dapat menyelesaikan masalah dengan berpikir jernih.

Ketiga, bagi peneliti selanjutnya. Perlu ada penelitian untuk mengkaji ulang pola hubungan antar variabel penelitian. Dukungan sosial bukan merupakan prediktor bagi kecemasan berbicara di muka umum, akan tetapi perlu diuji lebih lanjut apakah dukungan sosial menjadi prediktor bagi konsep diri. Dengan kata lain, perlu dipertimbangkan konsep diri sebagai intervening variable atau variabel antara yang menghubungkan dukungan sosial dengan kecemasan berbicara di muka umum.

\section{DAFTAR PUSTAKA}

Alwi, N. 2002. Hubungan antara efikasi diri dan dukungan sosial dengan kecemasan berbicara di muka umum pada remaja di Panti Asuhan. Tesis. Yogyakarta: Pro- gram Pascasarjana Universitas Gadjah Mada.

Burgoon, M. \& Ruffner, M. 1978. Human communication. New York, NY: Holt Rinehart and Winston Inc.

Burns, R.B. 1979. The self concept: Theory, measurement, development and behavior. New York, NY: Logman Inc.

Cohen, S. \& Syme, S.L. 1985. Issue in the study and application of social support: Social support and healt. London: Academic Press Inc.

Davidson, G.C. \& Neale, J.M. 1974. Abnormal Psychology: An experimental clinical approach $\left(2^{\text {nd }} e d\right)$. New York, NY: John Willey \& Sons Inc.

Devito, J.A. 1995. The interpersonal communication book $\left(7^{\text {th }} e d\right)$. New York, NY: Harper Collins College Publisher.

Ganster, D.C, Fusilier, M.R. \& Mayer, B.T. 1986. Role of social support in the experience of stress at work. Journal of Applied Psychology, 71, 102-110.

Gilmer, B.V. 1975. Applied psycholkogy: Adjustments in living and work. New Dehli: Tata McGraw-Hill Publishing Company Ltd.

Halgin, R.P. \& Whitbourne, S.K. 1994. Abnormal psychology: The human experience of psychological disorder. USA: Harcourt Brace College Publishers.

Hurlock, E.B. 1979. Personalitu development. New Dehli: McGraw-Hill.

Hurt, H.T. 1978. Communication in the class room. Menlopark: Addison Wesley.

Johnson, D.W. \& Johnson, F.P. Joining together: Group therapy and group skill. Englewood Cliffs: Prentice-Hall, Inc.

Lingren, H.C. \& Hyme, D. 1971. Psychology: An introduction to a behavioral science. New York, NY: John Willey and Sons.

Mermelmstein, R., Cohen, S., Lichenstein, E., Baer., J.S., \& Kamarck, T. 1986. Social support and smoking cessation and maintenance. Journal of Consulting and Clinical Psychology, 54, 447-453.

Partosuwido, S.R. 1992. Penyesuaian diri mahasiswa dalam kaitannya dengan konsep diri, pusat kendali dan status perguruan tinggi. Disertasi. Program Pascasarjana Universitas Gadjah Mada. 
Rackmat, J. 1985. Psikologi komunikasi. Bandung: Rosdakara.

Sarafino, E.P. 1998. Health psychology: Biopsychosocial interaction $\left(3^{\text {rd }} e d\right)$. New York, NY: John Wiley \& Sons, Inc. Sarason, I.G., Levine, H.M., Basham, R.B. \& Sarason B.R. 1983. Assessing social support, the social support questionnaire. Journal of Personality and Social Psychology, 44, 127-139.

Secord, P.F. \& Backman, C.W. 1974. Social Psychology ( $2^{\text {nd }}$ ed). Tokyo: McGrawHill, Koghakusha Ltd.

Shevelson, R.J. \& Bolus, R. 1982. Self concept: The interplay of theory and methods. Journal of Educational Psychology,
Tjipsastra, F.E. 1996. Hubungan antara konsep diri, motivasi berprestasi dengan prestasi belajar anak-anak panti asuhan dan perbedaannya dari anak-anak yang diasuh dalam keluarga. Tesis. Jakarta: Program Pascasarjana Universitas Indonesia.

Trefina, I. 1990. Hubungan antara konsep diri dengan kecemasan komunikasi oral pada mahasiswa FIP, FPBS, FPIPS di IKIP Negeri Yogyakarta. Skripsi. Yogyakarta: Fakultas Posikologi Universitas Gadjah Mada.

Whalen, D.J. 1996. I see what you mean. California: Sage Publication. 